\title{
Development of the Intestinal Bacterial Composition in Hospitalized Preterm Infants in Comparison with Breast-Fed, Full-Term Infants
}

\author{
ANDREAS SCHWIERTZ, BÄRBEL GRUHL, MANUELA LÖBNITZ, PETER MICHEL, \\ MICHAEL RADKE, AND MICHAEL BLAUT \\ Deutsches Institut für Ernaehrungsforschung, Abteilung Gastrointestinale Mikrobiologie, 14558 \\ Bergholz-Rehbrücke, Germany [A.S., B.G., M.B.], Klinik für Kinder und Jugendliche, Klinikum Ernst von \\ Bergmann, 14467 Potsdam, Germany [M.L., P.M., M.R.]
}

\begin{abstract}
ABSTR
The establishment and succession of bacterial communities in
hospitalized preterm infants has not been extensively studied.
Because earlier studies depended on classical cultural techniques,
their results were limited. This study monitored the establishment
and succession of the neonatal microbiota in the first weeks of
life by analyzing the $16 \mathrm{~S}$ rDNA variety in fecal samples applying
PCR-denaturing gradient gel electrophoresis (PCR-DGGE). Fe-
cal samples from 29 preterm infants hospitalized in a neonatal
intensive care unit, including samples from antibiotic-treated
infants and one with neonatal necrotizing enterocolitis, were
subjected to PCR-DGGE analysis. Daily DGGE profiles from all
preterm infants during the first 4 wk were obtained and analyzed.
In addition, feces of 15 breast-fed, full-term infants and a variety
of clinical bacterial isolates were examined and compared with
the PCR-DGGE profiles of the preterm infants. During the first
days of life, the DGGE profiles were rather simple but increased
in their complexity over time. It became obvious that not only the
intraindividual band-pattern similarity increased over time, but
\end{abstract}
also the interindividual. During the observation period, similarity values $\left(\mathrm{C}_{\mathrm{s}}\right)$ increased in each preterm infant from 0 to $80 \%$, whereas interindividual $\mathrm{C}_{\mathrm{s}}$ increased from 18.1 to $57.4 \%$, revealing the acquisition of a highly similar bacterial community in these infants. In contrast, $\mathrm{C}_{\mathrm{s}}$-values obtained for breast-fed, full-term infants were rather low (11.2\%). Escherichia coli, Enterococcus sp., and Klebsiella pneumoniae were the bacteria most commonly found in all preterm infants. The interindividual bacterial composition in hospitalized preterm infants is more similar in comparison with breast-fed, full-term infants and is not necessarily influenced by birth weight, diet, or antibiotic treatment. (Pediatr Res 54: 393-399, 2003)
$\mathbf{C}_{\mathbf{s}}$, Sorenson's pair-wise similarity coefficient
DGGE, denaturing gradient gel electrophoresis
GI, gastrointestinal
NEC, necrotizing enterocolitis

The GI tract of a normal fetus is sterile. During the birth process and rapidly thereafter, microbes from the mother and the surrounding environment colonize the gastrointestinal tract of the infant until a dense, complex bacterial community is established. This enteric flora contributes not only to health by facilitating carbohydrate assimilation (1) and interaction with the developing immune system $(2,3)$, it also plays a significant role in disease (4-6). A dynamic balance exists between the GI bacterial community, host physiology, and diet, all of which influence the initial acquisition, developmental succession, and eventual stability of the gut ecosystem (7). In the birth process and soon thereafter, bacterial colonization starts and facultative

Received July 31, 2002; accepted January 6, 2003.

Correspondence: Andreas Schwiertz, Ph.D., SymbioHerborn Group, Auf den Lueppen 8, D-35745 Herborn, Germany; e-mail: andreas.schwiertz@mikrooek.de

Current address for A.S.: SymbioHerborn Group, Auf den Lueppen 8, 35745 Herborn, Germany.

DOI: 10.1203/01.PDR.0000078274.74607.7A anaerobic bacteria such as enterobacteria appear in feces. Because at this stage the composition of the gut bacterial community is strongly influenced by the diet, a shift in the bacterial composition can be observed $(3,8)$. A breast-fed, full-term infant shows a fecal bacterial composition in which bifidobacteria predominate over potentially harmful bacteria, whereas, in formula-fed infants, coliforms, enterococci, and bacteroides predominate $(8-11)$. The process of colonization is greatly influenced by the successive shifts from formula feeding to weaning and finally to the introduction of solid food.

Although several studies monitored the bacterial communities in infants $(8,12)$, our picture of the neonatal microbiota is still limited, because the classical cultivation techniques only allow the identification of a limited number of bacteria. In recent years, the use of $16 \mathrm{~S}$ rRNA gene sequences has greatly facilitated the study of GI tract ecology (13) because it allows the culture-independent analysis of the fecal microbiota. The rRNA gene sequences comprise highly conserved sequence 
domains interspersed with more variable regions. Consequently, comparative analyses of rRNA sequences can identify so-called signature sequence motifs. The simplest and currently the most widely used method to obtain $16 \mathrm{~S}$ rRNA genes from fecal samples is through the use of PCR. rRNA genes can be amplified directly from total community DNA using rRNAspecific primers. By taking advantage of the highly conserved nature of rRNA, universal primers capable of annealing to rRNA genes from all three domains (Archea, Bacteria, Eukarya) or primers designed to amplify rRNA genes from a particular group of organisms can be used (14-18).

One of the 16S rRNA-gene based techniques is PCR-DGGE, a technique in which DNA is isolated from fecal samples and amplified by PCR using conserved $16 \mathrm{~S}$ rDNA bacteria-domain primers $(16,17)$. In practice, total bacterial DNA from fecal samples is extracted and a region with a hypervariable nucleotide base sequence of the 16S rDNA gene is amplified by specific PCR primers. One of these bacteria-domain primers has a so-called " $\mathrm{G}+\mathrm{C}$ clamp" of approximately 39 nucleotides attached to the 5 ' end. This " $\mathrm{G}+\mathrm{C}$ clamp" prevents the two DNA strands from dissociating completely, even under highly denaturing conditions. The resulting mixture of $16 \mathrm{~S}$ rDNA fragments is subjected to a denaturing gradient, established in a polyacrylamide gel with urea and formamide, to separate the fragments and generate a "genetic fingerprint" of the microbiota present. Although all PCR products are of approximately equal size, individual amplicons stop to migrate as the double-stranded products denature according to their $\mathrm{G}$ $+\mathrm{C}$ content. This approach thus allows separation of individual sequences based on $\mathrm{G}+\mathrm{C}$ content, corresponding to the different microbial species within the sample. The vertical orientation of the denaturing gradient facilitates the simultaneous screening of many samples.

In a recent study, Favier et al. (19) used PCR-DGGE to study the development of the infant flora for up to $12 \mathrm{mo}$. They were able to show that band patterns during the first days of life were very simple, but they became more complex over time.

In contrast, not much information concerning the composition of the bacterial community of premature infants is available at the moment. Previous studies of the gut microbial community in premature infants relied on the application of classical cultural methods, and showed that these infants harbored a rather simple bacterial community (20-22). So far, only one study inspected the microbial composition of premature infants by molecular methods (23).

The purpose of this study was to obtain information on the fecal bacterial community of premature infants in comparison with breast-fed, full-term infants. A further goal of this study was to determine whether bacterial strains, which have been routinely isolated by classical cultural methods in the baby care unit, are major representatives of the premature infants' fecal composition.

\section{MATERIAL AND METHODS}

Subjects. The protocol of this study was submitted to the ethics commission of the Brandenburg state medical association, which approved the study without further consultation because the study solely involved stool analyses but not the examination of patients just for the study. Informed consent was obtained from the parents of the children who took part in this study. In the period April 2001 to January 2002, 29 preterm infants were delivered between wk 24 and 37, either vaginally (11 infants) or by cesarean section (18 infants), with a birth weight ranging from 830 to $2635 \mathrm{~g}$. All infants were born in the Ernst von Bergman Klinikum, Potsdam, stayed for at least $4 \mathrm{wk}$ in a baby incubator in the neonatal intensive care unit, and were subjected to a feeding regime reported earlier (22). All full-term infants (15 infants) were fully breast-fed, delivered vaginally on time, and were not hospitalized.

Preparation of samples. After birth, fecal samples of 29 premature infants were taken daily for $2 \mathrm{wk}$ and on d 17, 21, 24 , and 28. During the study period, seven infants showed high IL-6 levels (preterm infants no. 4, 9, 18, 19, 22, 23, and 28) and hence received an antibiotic treatment. All of these infants were subjected to a standard antibiotic therapy, receiving in the first $3 \mathrm{~d}$ cefotaxime $(200 \mathrm{mg} / \mathrm{kg} / \mathrm{d})$ and piperazine $(150 \mathrm{mg} / \mathrm{kg} /$ d). After d 3, vancomycin (15 mg/kg/d) and amikacin (15 $\mathrm{mg} / \mathrm{kg} / \mathrm{d}$ ) were given until the inflammation was reduced. Fecal samples were collected during the whole observation period. One of these infants, treated from $\mathrm{d} 2$ on, died from NEC on the d 4. Therefore, fecal samples from this infant could only be obtained on $\mathrm{d} 1$ and 3 after birth. In addition, fecal samples were taken from 15 full-term infants $6 \mathrm{~d}$ after delivery. All samples were stored at $4{ }^{\circ} \mathrm{C}$ until further processing.

Organisms and culture conditions. All strains used in this study are isolates obtained and identified during routine testing in the neonatal intensive care unit of the Department of Pediatrics of the Ernst von Bergmann Klinikum. Species identification was achieved by using the automated identification system Vitek (Bio Mérieux, Nürtingen, Germany), which is commonly used in hospitals for bacteria identification. The system allows the identification of aerobic and anaerobic bacteria down to the species level. However, the system is not able to distinguish between strains. In this study, we used the most frequently isolated bacterial species. For further analysis, all isolates were cultured at $37^{\circ} \mathrm{C}$ under oxic conditions on blood agar plates (Bio Mérieux).

DNA extraction. For DNA extraction, $100 \mathrm{mg}$ of fresh feces (wet weight) were homogenized in $1 \mathrm{~mL}$ TN $150[10 \mathrm{mM}$

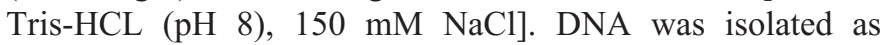
described earlier $(19,24)$.

For DNA extraction, bacterial cultures were grown aerobically overnight on blood agar plates. The cells were harvested and subjected to nucleic-acid extraction following protocol number 5 of the InViTek DNA-Isolation Kit III (InViTek $\mathrm{GmbH}$, Berlin, Germany).

PCR amplification for DGGE. Primers U968-GCf (5' CGC CCG GGG CGC GCC CCG GGC GGG GCG GGG GCA CGG GGG GAA CGC GAA GAA CCT TAC) and L1401-r (5' CGG TGT GTA CAA GAC CC) (25) were used to amplify the V6-V8 regions of the bacterial 16S rRNA from all infants. In addition, bifidobacteria-specific primers Bifl64- $f$ (5' GGG TGG TAA TGC CGG ATG) and Bif662-GC-r (5' CGC CCG CCG CGC GGC GGG CGG GGC GGG GGC ACG GGG GG CCA CCG TTA CAC CGG GAA) $(15,26,27)$ were used to 
perform PCR. Nucleotides comprising the " $\mathrm{G}+\mathrm{C}$ clamps" are underlined.

PCR were performed with a Taq polymerase kit from InViTek (Berlin, Germany). Each 50- $\mu \mathrm{L}$ mixture contained deoxynucleoside triphosphate at a concentration of $10 \mathrm{mM}, 2.5 \mathrm{U}$ of Taq polymerase, $10 \mu \mathrm{mol}$ of each primer, and $1 \mu \mathrm{L}$ of a DNA solution obtained from the fecal and pure culture DNA extractions, respectively. PCR amplification was performed with a PCR thermal cycler (Hybaid, Heidelberg, Germany) under the following conditions: denaturation at $94^{\circ} \mathrm{C}$ for $5 \mathrm{~min}$, followed by 35 cycles of denaturation at $94^{\circ} \mathrm{C}$ for $30 \mathrm{~s}$, annealing at $56^{\circ} \mathrm{C}$ for $20 \mathrm{~s}\left(62^{\circ} \mathrm{C}\right.$ for $20 \mathrm{~s}$ for Bifl $64-f$ and Bif662-r primers), and extension at $68^{\circ} \mathrm{C}$ for $40 \mathrm{~s}$. After completion, an additional extension step was performed at $68^{\circ} \mathrm{C}$ for $7 \mathrm{~min}$, and the samples were then chilled to $4^{\circ} \mathrm{C}$.

DGGE of PCR amplicons. PCR fragments were separated by DGGE as described earlier $(16,24)$ using the Decode system (Bio-Rad, Hercules, CA, U.S.A.), with the following modifications. Polyacrylamide gels (dimensions, $200 \times 200 \times$ $1 \mathrm{~mm}$ ) consisted of $8 \%(\mathrm{vol} / \mathrm{vol})$ polyacrylamide (ratio of acrylamide-bisacrylamide, $37.5: 1)$ and $0.5 \times$ Tris-acetateEDTA (TAE, pH 8.0) buffer; $100 \%$ denaturing acrylamide was defined as $7 \mathrm{M}$ urea and $40 \%$ formamide. The gels were poured from the top by using a gradient maker and a pump (Econopump, Bio-Rad) set at a speed of $4 \mathrm{~mL} / \mathrm{min}$. We used $40-60 \%$ gradients to separate products amplified with universal primers. For the separation of products generated with the bifidobacteria-specific primers, we used a $45-55 \%$ gradient (15). Before polymerization of the gel, a stacking gel without denaturing chemicals was added, and an appropriate comb was subsequently inserted. Electrophoresis was performed first for $5 \mathrm{~min}$ at $200 \mathrm{~V}$ and subsequently overnight at $85 \mathrm{~V}$ in $0.5 \times$ TAE buffer at a constant temperature of $60^{\circ} \mathrm{C}$. The gels were stained with $\mathrm{AgNO}_{3}$ as previously described (28). To allow a comparison between PCR-DGGE gels, internal standards were used. These standards consisted of Enterococcus sp., Escherichia coli, and Klebsiella pneumoniae, all of which were isolated in the neonatal intensive care unit. Each internal standard resulted in one prominent band, which allowed their specific distinction and identification in the fecal samples. In addition, the following species commonly isolated in the neonatal intensive care unit were used for band identification: Citrobacter freundii, Enterobacter cloacae, Enterobacter aerogenes (Klebsiella mobilis), Pseudomonas aeruginosa, Staphylococcus aureus, and Staphylococcus epidermidis.

Estimation of microbial richness and diversity. The richness and diversity of the preterm and full-term infant fecal microbiota was estimated from the number of PCR-DGGE bands present (29). Each lane in a DGGE gel represents one given time point during the observation period. The band numbers and frequencies within a given infant were compared for various time points and between different infants. "Species" used in the indices refer to individual bands on the PCR-DGGE gels. These indices measure ecological diversity using various parameters, including species richness (the number of different species) and evenness (the distribution of individual species in the ecosystem) (30). Band number corresponds to the number of individual bands in a single lane. Band frequency was calculated by measuring the percentage of all samples at a given time point containing a specific band. $\mathrm{C}_{\mathrm{s}}$ was used to quantify similarity $(31-33) . \mathrm{C}_{\mathrm{s}}$ values were determined by the following equation:

$$
\mathrm{C}_{\mathrm{s}}=\left[\frac{2 \mathrm{j}}{(a+b)}\right] \times 100
$$

Where $a$ is the number of PCR-DGGE bands in lane $1, b$ is the number of PCR-DGGE bands in lane 2 , and $j$ is the number of common PCR-DGGE bands (30). Thus, two identical profiles will give a $\mathrm{C}_{\mathrm{s}}$ value of $100 \%$, whereas completely different profiles result in $0 \%$ similarity. Each sample of a given time point was compared with every other sample; therefore, mean percentage similarities $\left(\mathrm{C}_{\mathrm{s}}\right.$ values $)$ can be compared for each time point in relation to other time points. A high $\mathrm{C}_{\mathrm{s}}$ value indicates a highly similar PCR-DGGE pattern, which indicates a high similarity in microbiota composition.

Statistics. The data for each time point of the observation period are given as mean \pm SD of 27 preterm infants and 15 full-term infants. Differences between the means were checked for significance by the paired $t$ test, as described by Lorenz (34), and are indicated as $p$ values.

\section{RESULTS}

Molecular analysis by DGGE of the fecal bacterial community of preterm and full-term infants. To characterize and compare bacterial succession in the large intestine of infants, fecal samples from 29 preterm infants and 15 full-term infants were analyzed using PCR-DGGE (Figs. 1-4). The investigation period extended over several months, as most of the infants were hospitalized at different times. Several bacteria commonly isolated from infants during routine microbial testing were included in the analysis (Table 1).

The strategy involved the extraction of DNA from fecal samples or selected bacterial strains followed by amplification with PCR of a fragment corresponding to region V6-V8 of the 16S rRNA gene using universal bacterial primers. In addition, bifidobacteria-specific primers were used for the fecal analysis of breast-fed, full-term infants. Analysis of PCR products by DGGE results in a fingerprint that represents the diversity of the rDNA nucleotide sequences originating from the various bacterial population groups present in the ecosystem. The bands in the profile represent most of the dominant microbial populations in the community, and their appearance and disappearance reflect changes in the microbial community composition. The intensity of the band may provide an estimate of the proportion of the target sequence in the respective sample.

Bacterial succession in preterm and full-term infants. The DGGE profiles of all preterm infants showed a low diversity in the $16 \mathrm{~S}$ rDNA sequences during the first $3 \mathrm{~d}$. Only a few bands were present and varied from one to several major bands. Following d 4 after birth, the band pattern became more constant in most infants. Ten days after birth, the band pattern became stable, with only minor changes (Fig. 1). The number of major bands in individual babies ranged from five to 20 . Interestingly, the band patterns became increasingly similar in 


\section{Pre-term infant No. 1}

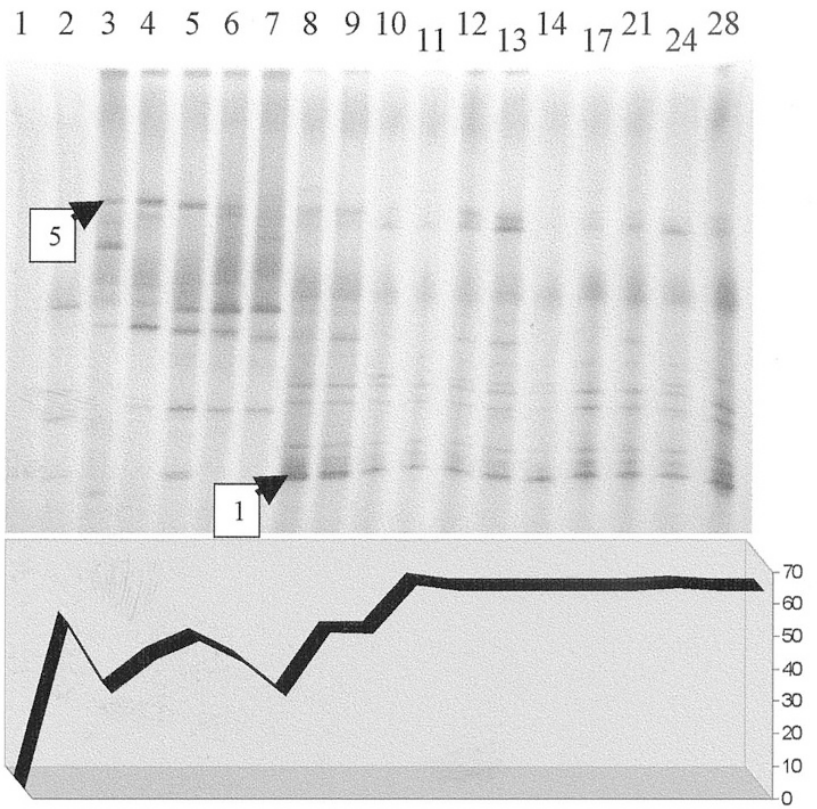

\section{Pre-term infant No. 17}

$\begin{array}{lllllllllllllllll}2 & 3 & 4 & 5 & 6 & 7 & 8 & 9 & 101112 & 1314 & 172124 & 28\end{array}$

days

Figure 1. PCR-DGGE profiles representing the bacterial diversity in preterm infants 1 and 17 generated from samples taken on the indicated days. Band patterns do not represent the same positions in the PCR-DGGE gels. The bands identified from the PCR-DGGE profiles of known species are numbered and indicated by arrowheads. Numbers correspond to the numbers given in Table 1. Below the PCR-DGGE profiles, the band pattern similarity is illustrated for each infant over time.

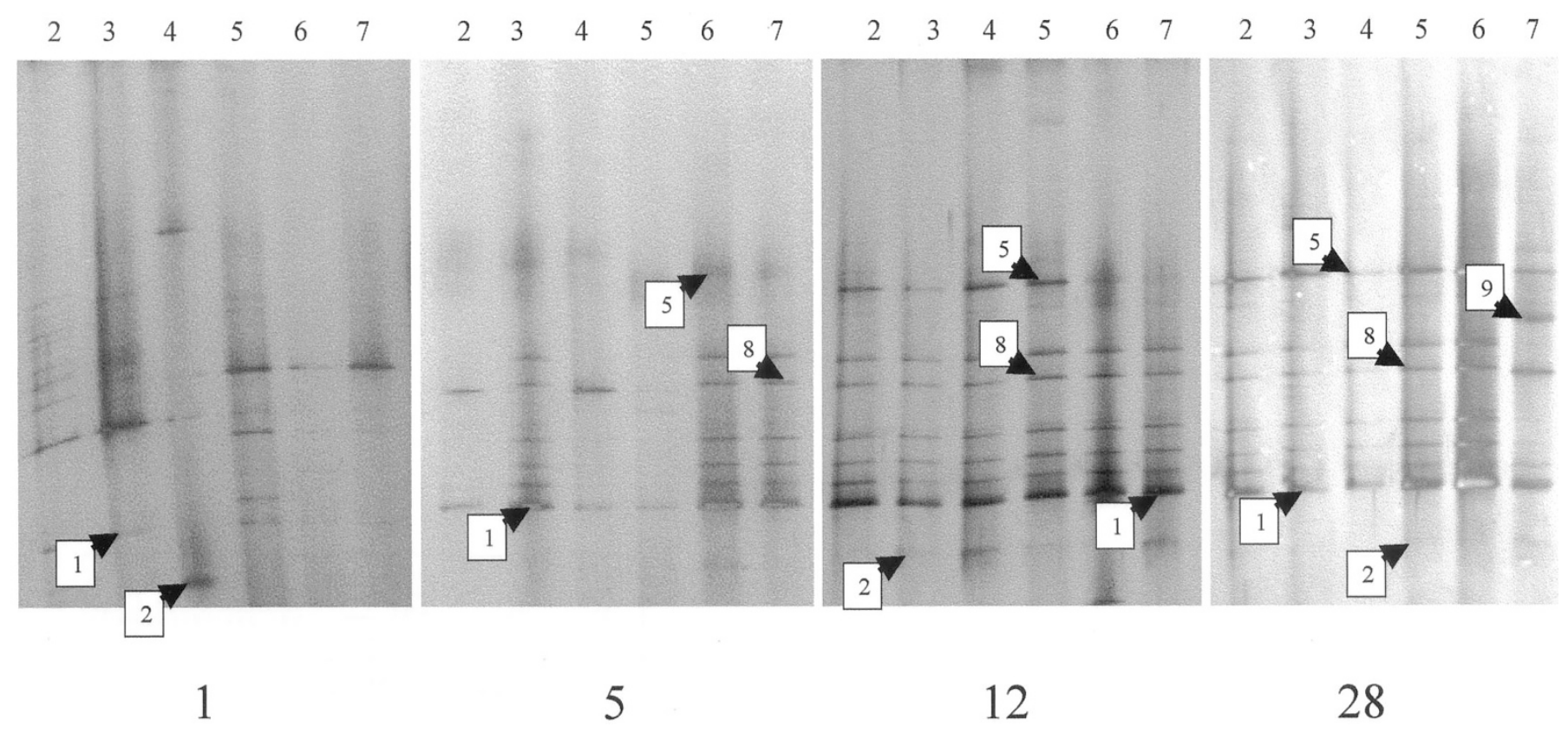

Figure 2. PCR-DGGE profiles representing the bacterial diversity in six of the tested 29 preterm infants are illustrated. Numbers on top indicate the specific preterm infant. Numbers below the gels refer to the sampling days after birth. Bands identified from PCR-DGGE profiles of known species are numbered and indicated by arrowheads. Numbers correspond to the numbers given in Table 1.

most infants after the wk 2 (Fig. 2). Several of the hospital isolates could be identified in the fecal samples (Figs. 1-3).

DGGE-profiles were obtained from full-term infants at one time point after the $\mathrm{d} 5$ of life. In contrast to the preterm infants, the emerging band patterns were more diverse in the full-term infants. The number of the major bands varied from one to 12 (data not shown). There were few similarities in the band patterns between the individual infants. Using bifidobacteria-specific PCR-DGGE primers, several bands were obtained indicating that bifidobacteria made up the majority of species present (data not shown).

Comparison of fecal bacterial diversity. The quantity of samples containing specific PCR-DGGE bands was calculated to characterize the distribution frequency of these bands among 


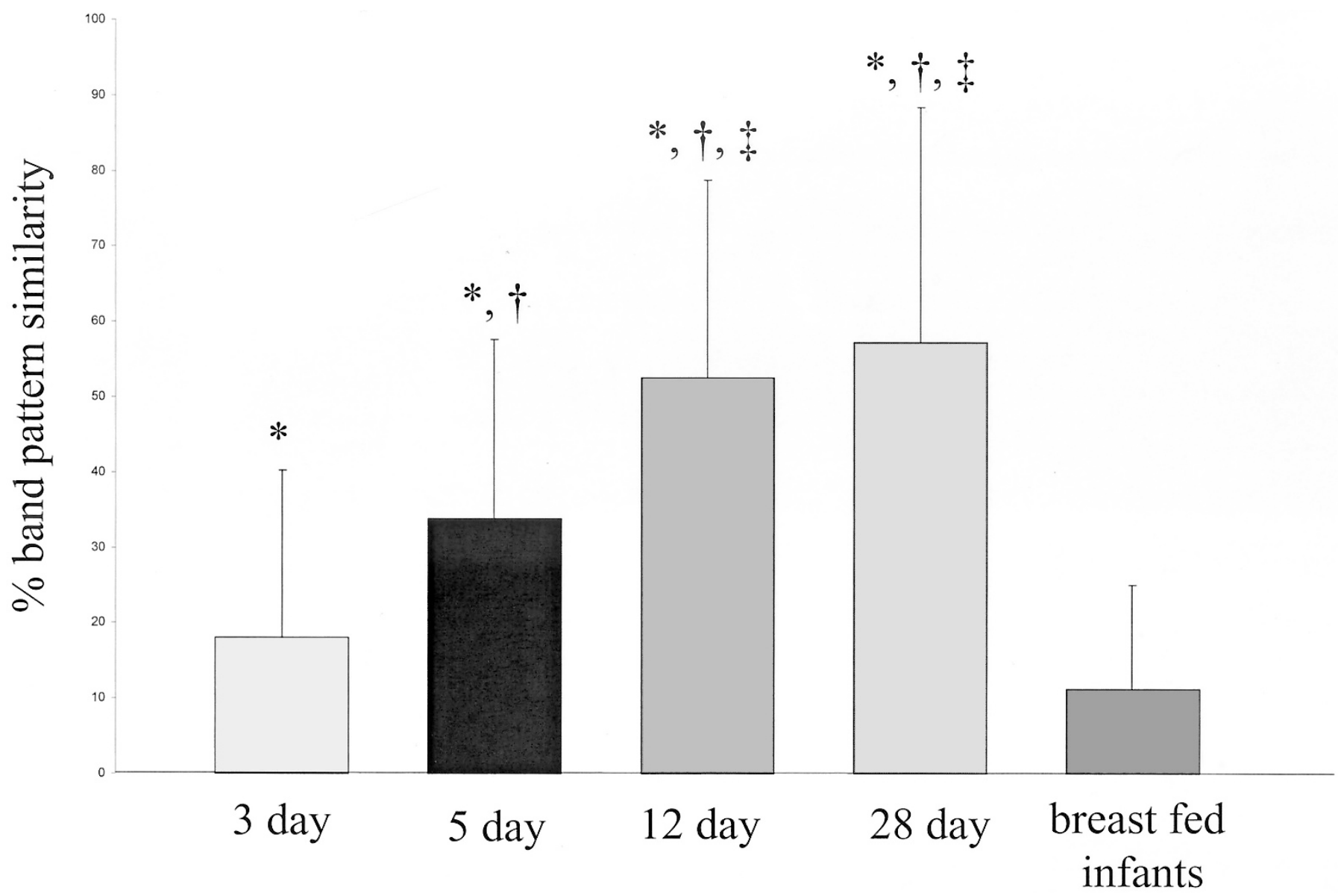

Figure 3. Percentage of similarities for PCR-DGGE banding patterns from fecal samples of preterm infants from the given time period. In addition, the similarity value for full-term, breast fed infants is given. *Significantly more similar than breast-fed infants $(p<0.05)$. † Significantly more similar than on $\mathrm{d}$ $3(p<0.05)$. $t$ Significantly more similar than on d $5(p<0.05)$. For further information, see "Material and Methods."

the different sample days. It was apparent that the similarity of the PCR-DGGE band patterns increased over time (Figs. 1 and 3). Similarity values $\left(\mathrm{C}_{\mathrm{s}}\right)$ for the various time points in each infant increased from 0 to over 70 or $80 \%$ (Figs. 1 and 3), whereas similarity between the individual preterm infants increased from 18.1 to $57.4 \%$ over time (Fig. 3). Several of the bacterial species routinely isolated from feces in the neonatal intensive care unit resulted in DGGE bands that were also observed in the profiles of the fecal samples analyzed. Bands corresponding to E. coli, Enterococcus sp., and K. pneumoniae were the most common in the preterm infants.

Profiles of full-term infants were only obtained at d 6 after birth. The $\mathrm{C}_{\mathrm{s}}$ value of $11.2 \%$ in these infants was considerably lower than in the preterm infants, indicating that the composition of the bacterial community was highly variable between individual full-term infants.

Bacterial succession in antibiotic-treated preterm infants. The total antibiotic-treatment period in the prophylactically treated infants varied from three to $21 \mathrm{~d}$. It is obvious that the bacterial community was not affected in any of these infants. For instance, in preterm infant no. 9, who was treated from his/her first to fourth day of life with antibiotics, a complex DGGE band pattern was even observed during the antibiotic regime (Fig. 4). The $\mathrm{C}_{\mathrm{s}}$ value for this infant increased from 50 to more than $80 \%$ over the study period. Interestingly, this infant showed a rather complex band pattern, comparable to the infants not treated with antibiotics. However, for an antibiotic-treated infant, one might expect lower band pattern diversity.

In contrast, preterm infant no. 22 was treated with antibiotics from day 5-21. After antibiotic treatment, the numbers of bands was reduced, but remained stable until d 10. Beginning with $\mathrm{d} 10$, a new band pattern established, but the complexity of the band pattern appeared to be low in comparison to that of infant no. 9 (Fig. 4). $\mathrm{C}_{\mathrm{s}}$ values of the PCR-DGGE bands increased from 28 to $80 \%$ in this and the other antibiotictreated preterm infants (nos. 4, 18, 19, and 23), who showed a comparable band pattern evolution (data not shown).

Preterm infant no. 28 received an antibiotic treatment from his/her second day on. This infant was diagnosed with NEC on the third day and subsequently died thereof. Two fecal samples from this infant were collected. Both samples showed a highly diverse band pattern, indicating that several bacterial species were present in the intestine at birth already (Fig. 4).

\section{DISCUSSION}

In the present study, we used samples obtained from preterm infants in their first 4 wk of life to follow the succession of the dominant bacterial species. We could show that the PCR- 


\section{Pre-term infant no. 9}

Pre-term infant no. 22

$\begin{array}{llllllllllllllllll}1 & 2 & 3 & 5 & 6 & 7 & 8 & 9 & 10 & 11 & 12 & 13 & 14 & 17 & 21 & 24 & 28\end{array}$

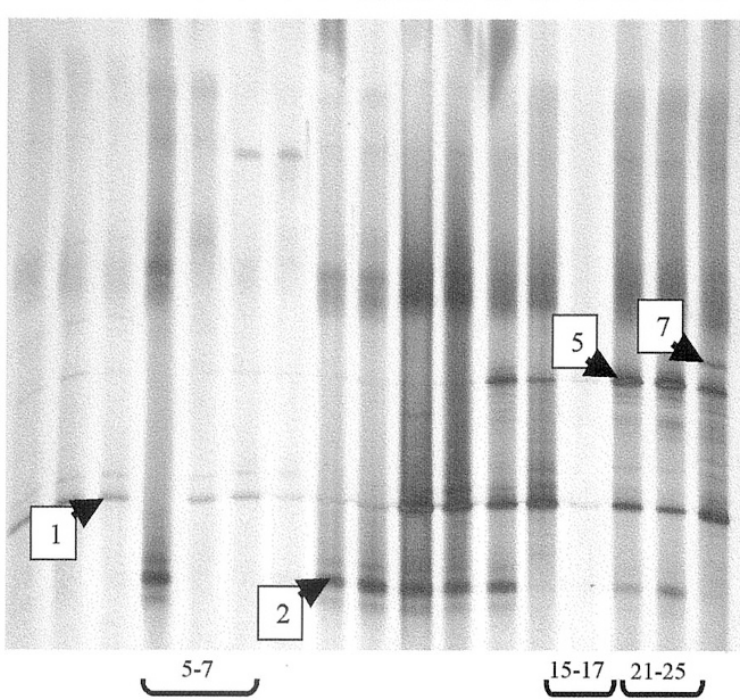

NEC infant

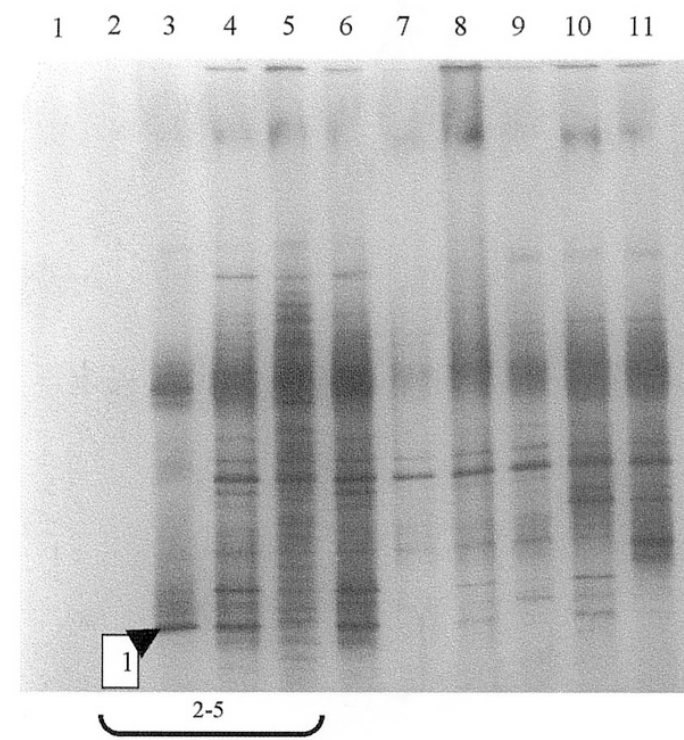

Figure 4. PCR-DGGE profiles representing the successive bacterial diversity in antibiotic-treated preterm infants and an infant diagnosed with NEC. Band patterns do not represent the same positions in the PCR-DGGE gels. Brackets indicate the time period of antibiotic treatment. Bands identified from PCR-DGGE profiles of known species are numbered and indicated by arrowheads. Numbers correspond to the numbers given in Table 1 .

Table 1. Bacteria commonly found during routine microbial testing in the neonatal intensive care unit

\begin{tabular}{clc} 
& & Band Pattern \\
No. & \multicolumn{1}{c}{ Bacteria Cultured and Identified } & $\begin{array}{c}\text { Identified in } \\
\text { PCR-DGGE }\end{array}$ \\
\hline 1. & Escherichia coli & + \\
2. & Enterococcus sp. & + \\
3. & Enterobacter aerogenes (Klebsiella mobilis) & \\
4. & Enterobacter cloacae & + \\
5. & Klebsiella pneumoniae & \\
6. & Staphylococcus aureus & + \\
7. & Staphylococcus epidermidis & + \\
8. & Pseudomonas aeruginosa & + \\
9. & Citrobacter freundii & \\
\hline
\end{tabular}

DGGE patterns for all preterm infants were very simple at birth and that the diversity increased over time. These results are comparable to an earlier study (19). We could also show that the band profiles of our preterm infants became more similar to each other over time, indicating that all preterm infants harbored a similar bacterial composition. These results confirm previous studies, in which it was shown that cross-transmission of bacteria is a serious problem in hospitals $(35,36)$. In contrast to the 29 preterm infants, who showed a highly similar band pattern, the band patterns of breast-fed, full-term infants showed little similarity, indicating that the breast-fed, full-term infants acquired bacterial communities whose composition displayed much less similarity between individual infants in this group and also in comparison to the preterm hospitalized infants. This is also reflected by the rather low similarity index $\left(\mathrm{C}_{\mathrm{s}}\right)$ of band patterns in the preterm infants. In contrast, the preterm hospitalized infants had an increasing $\mathrm{C}_{\mathrm{s}}$ value over time. Several of the bands in the DGGE gels of the breast-fed, full-term infants, but not in the preterm infants, could be attributed to bifidobacteria. So far, only a few studies followed the bacterial succession in preterm infants $(23,37-39)$.

Hospitalization is known to have serious effects on bacterial composition (40). In the present study, we were able to show that preterm infants acquire a rather diverse bacterial community after birth, but, as a result of hospitalization, tend to develop a similar strain composition over time. This may indicate subject-specific factors responsible for the acquisition of the bacterial community in the GI tract, as put forward by Zoetendal et al. (41). The authors were able to show a positive relationship between the similarity indices for PCR-DGGE band patterns, which represent the bacterial community, and the genetic relatedness of the hosts. With regard to our results, the acquisition of a specific bacterial community is dependent on host factors and environmental factors, which, because of hospitalization, are altered. The composition of the neonatal fecal bacterial community is of great interest, as it is hypothesized that an inappropriate colonization of the premature intestine may play a role in the development of NEC (42). In our study, one hospitalized infant died of NEC during the course of the study. It is noteworthy that this incidence does not represent the average prevalence for NEC in the Ernst von Bergmann Klinikum, which is three out of 200 preterm infants. In the two fecal samples taken before death, a highly diverse band pattern became obvious. Because only one infant was diagnosed with NEC, we were not able to draw any realistic conclusion from this event on the role of the of bowel microbiota in premature infants in NEC. Nevertheless, it is worthwhile to note that the microbiota of this premature infant was already highly diverse at birth.

The PCR-DGGE method has the advantage of being independent of culturing, which may favor the growth of certain bacterial groups and prevent the growth of others, resulting in 
a biased view of the bacterial community. However, the PCRDGGE approach can also lead to some distortions, as some sequences may amplify better than others, and heteroduplexes may be formed during PCR (43). Because PCR-DGGE bands correspond to the relative $\mathrm{G}+\mathrm{C}$ content of the amplified V6-V8 region of the $16 \mathrm{~S}$ rDNA, bacterial species with similar $\mathrm{G}+\mathrm{C}$ content in this amplified region may form assemblages and appear as a single band, resulting in fewer bands (17). Thus, PCR-DGGE experiments may not reflect the total composition of the bacterial community present. In addition, the presence of intragenomic $16 \mathrm{~S}$ rDNA heterogeneity in bacteria strains may hamper the results (15).

In summary, we were able to show an increase in similarity of the bacterial communities in hospitalized preterm infants in contrast to breast-fed, full-term infants. A strikingly high similarity was observed between bacterial communities from different preterm infants regardless of birth weight, feeding regime, and antibiotic therapy, respectively, in contrast to fullterm, breast fed infants. This result supports the notion that the initial colonization of the newborn's GI tract is highly dependent on the environment.

\section{REFERENCES}

1. Kien CL, Liechty EA, Myerberg DZ, Mullett MD 1987 Dietary carbohydrate assimilation in the premature infant: evidence for a nutritionally significant bacterial ecosystem in the colon. Am J Clin Nutr 46:456-460

2. Kirjavainen PV, Gibson GR 1999 Healthy gut microflora and allergy: factors influencing development of the microbiota. Ann Med 31:288-292

3. Wold AE, Adlerberth I 2000 Breast feeding and the intestinal microflora of the infant-implications for protection against infectious diseases. Adv Exp Med Biol 478:77-93

4. Duffy LC 2000 Interactions mediating bacterial translocation in the immature intestine. J Nutr 130:432S-436S

5. McKay DM 1999 Intestinal inflammation and the gut microflora. Can J Gastroenterol 13:509-516

6. Linskens RK, Huijsdens XW, Savelkoul PH, Vandenbroucke-Grauls CM, Meuwissen SG 2001 The bacterial flora in inflammatory bowel disease: current insights in pathogenesis and the influence of antibiotics and probiotics. Scand J Gastroenterol Suppl:29-40

7. Hopkins MJ, Sharp R, Macfarlane GT 2001 Age and disease related changes in intestinal bacterial populations assessed by cell culture:16S rRNA abundance, and community cellular fatty acid profiles. Gut 48:198-205

8. Rubaltelli FF, Biadaioli R, Pecile P, Nicoletti P 1998 Intestinal flora in breast- and bottle-fed infants. J Perinat Med 26:186-191

9. Heine W, C. M, Wutzke KD 1990 Correlation between the intestinal microflora and whole-body protein metabolism in infants. In: Chapman TE, Berger R, Rejingoud DJ, Okken A (eds) Staple Isotopes in Pediatric Nutritional and Metabolic Research. Intercept, Andover, Hampshire, United Kingdom, pp 227-235

10. Heine W, Mohr C, Wutzke KD, Radke M 1991 Symbiotic interactions between colonic microflora and protein metabolism in infants. Acta Paediatr Scand 80:7-12

11. Heine W, Mohr C, Wutzke KD 1992 Host-microflora correlations in infant nutrition. Prog Food Nutr Sci 16:181-197

12. Cooperstock MS, Zedd AJ 1983 Intestinal flora of infants. In: Hentges DJ (ed) Human Intestinal Microflora in Health and Disease. Academic Press, New York, pp 79-99

13. Vaughan EE, Schut F, Heilig HG, Zoetendal EG, de Vos WM, Akkermans AD 2000 A molecular view of the intestinal ecosystem. Curr Issues Intest Microbiol 1:1-12

14. Walter J, Hertel C, Tannock GW, Lis CM, Munro K, Hammes WP 2001 Detection of Lactobacillus, Pediococcus, Leuconostoc, and Weissella species in human feces by using group-specific PCR primers and denaturing gradient gel electrophoresis. Appl Environ Microbiol 67:2578-2585

15. Satokari RM, Vaughan EE, Akkermans AD, Saarela M, de Vos WM 2001 Bifidobacterial diversity in human feces detected by genus-specific PCR and denaturing gradient gel electrophoresis. Appl Environ Microbiol 67:504-513

16. Muyzer G 1999 DGGE/TGGE a method for identifying genes from natural ecosystems. Curr Opin Microbiol 2:317-322
17. Muyzer G, Smalla K 1998 Application of denaturing gradient gel electrophoresis (DGGE) and temperature gradient gel electrophoresis (TGGE) in microbial ecology. Antonie Van Leeuwenhoek 73:127-141

18. Heilig HG, Zoetendal EG, Vaughan EE, Marteau P, Akkermans AD, de Vos WM 2002 Molecular diversity of Lactobacillus spp. and other lactic acid bacteria in the human intestine as determined by specific amplification of 16S ribosomal DNA. Appl Environ Microbiol 68:114-123

19. Favier CF, Vaughan EE, De Vos WM, Akkermans AD 2002 Molecular monitoring of succession of bacterial communities in human neonates. Appl Environ Microbiol 68:219-226

20. Bennet R, Eriksson M, Zetterstrom R 1981 Increasing incidence of neonatal septicemia: causative organism and predisposing risk factors. Acta Paediatr Scand 70:207210

21. Bennet R, Eriksson M, Nord CE, Zetterstrom R 1986 Fecal bacterial microflora of newborn infants during intensive care management and treatment with five antibiotic regimens. Pediatr Infect Dis 5:533-539

22. Sakata H, Yoshioka H, Fujita K 1985 Development of the intestinal flora in very low birth weight infants compared to normal full-term newborns. Eur J Pediatr 144:186190

23. Millar MR, Linton CJ, Cade A, Glancy D, Hall M, Jalal H 1996 Application of 16S rRNA gene PCR to study bowel flora of preterm infants with and without necrotizing enterocolitis. J Clin Microbiol 34:2506-2510

24. Zoetendal EG, Akkermans AD, De Vos WM 1998 Temperature gradient gel electrophoresis analysis of $16 \mathrm{~S}$ rRNA from human fecal samples reveals stable and host-specific communities of active bacteria. Appl Environ Microbiol 64:3854-3859

25. Nubel U, Engelen B, Felske A, Snaidr J, Wieshuber A, Amann RI, Ludwig W, Backhaus H 1996 Sequence heterogeneities of genes encoding 16S rRNAs in Paenibacillus polymyxa detected by temperature gradient gel electrophoresis. J Bacteriol 178:5636-5643

26. Langendijk PS, Schut F, Jansen GJ, Raangs GC, Kamphuis GR, Wilkinson MH, Welling GW 1995 Quantitative fluorescence in situ hybridization of Bifidobacterium spp. with genus-specific 16S rRNA-targeted probes and its application in fecal samples. Appl Environ Microbiol 61:3069-3075

27. Kok RG, de Waal A, Schut F, Welling GW, Weenk G, Hellingwerf KJ 1996 Specific detection and analysis of a probiotic Bifidobacterium strain in infant feces. Appl Environ Microbiol 62:3668-3672

28. Sanguinetti CJ, Dias Neto E, Simpson AJ 1994 Rapid silver staining and recovery of PCR products separated on polyacrylamide gels. Biotechniques 17:914-921

29. Simpson JM, McCracken VJ, Gaskins HR, Mackie RI 2000 Denaturing gradient gel electrophoresis analysis of $16 \mathrm{~S}$ ribosomal DNA amplicons To monitor changes in fecal bacterial populations of weaning pigs after introduction of Lactobacillus reuteri strain MM53. Appl Environ Microbiol 66:4705-4714

30. Magurran A 1988 Ecological Diversity and Its Measurement. Princeton University Press, Princeton, NJ

31. Leser TD, Lindecrona RH, Jensen TK, Jensen BB, Moller K 2000 Changes in bacterial community structure in the colon of pigs fed different experimental diets and after infection with Brachyspira hyodysenteriae. Appl Environ Microbiol 66:32903296

32. Murray AE, Hollibaugh JT, Orrego C 1996 Phylogenetic compositions of bacterioplankton from two California estuaries compared by denaturing gradient gel electrophoresis of 16S rDNA fragments. Appl Environ Microbiol 62:2676-2680

33. Simpson JM, McCracken VJ, White BA, Gaskins HR, Mackie RI 1999 Application of denaturant gradient gel electrophoresis for the analysis of the porcine gastrointestinal microbiota. J Microbiol Methods 36:167-179

34. Lorenz RJ 1992 Grundbegriffe der Biometrie. Gustav Fischer-Verlag, Jena, Germany

35. de Man P, van Der Veeke E, Leemreijze M, van Leeuwen W, Vos G, van Den Anker J, Verbrugh H, van Belkum A 2001 Enterobacter species in a pediatric hospital: horizontal transfer or selection in individual patients? J Infect Dis 184:211-214

36. Swartz MN 1994 Hospital-acquired infections: diseases with increasingly limited therapies. Proc Natl Acad Sci U S A 91:2420-2427

37. Blakey JL, Lubitz L, Campbell NT, Gillam GL, Bishop RF, Barnes GL 1985 Enteric colonization in sporadic neonatal necrotizing enterocolitis. J Pediatr Gastroenterol Nutr 4:591-595

38. Blakey JL, Lubitz L, Barnes GL, Bishop RF, Campbell NT, Gillam GL 1982 Development of gut colonisation in pre-term neonates. J Med Microbiol 15:519-529

39. Stark PL, Lee A 1982 The bacterial colonization of the large bowel of pre-term low birth weight neonates. J Hyg (Lond) 89:59-67

40. LeFrock JL, Ellis CA, Weinstein L 1979 The impact of hospitalization on the aerobic fecal microflora. Am J Med Sci 277:269-274

41. Zoetendal EG, Akkermanns AD, Akkermans-van Vliet WM, de Visser JA, de Vos WM 2001 The host genotype affects the bacterial community in the human gastrointestinal tract. Microb Ecol Health Dis 13:129-134

42. Claude EC, Walker WA 2001 Hypothesis: inappropriate colonization of the premature intestine can cause neonatal necrotizing enterocolitis. FASEB J 15:1398-1403

43. Wintzingerode FV, Göbel UB, Stackebrandt E 1997 Determination of microbial diversity in environmental samples: pitfalls of PCR-based rRNA analysis. FEMS Microbiol Rev 21:213-229 